\title{
Design and Fabrication of Double-cell Concrete Cube Moulds
}

\author{
Audu V. E. Michael, Mamman Y. Wakawa \\ Dept. of Civil Engineering Technology \\ The Fedreal Polytechnic \\ Mubi, Nigera
}

\author{
Jibrin Umar \\ Department of Civil Engineering Technology, \\ The Federal Polythecnic, \\ Damaturu, Nigeria
}

\begin{abstract}
The paper presents the design, materials, techniques, cost and fabrication of double-cell concrete cube moulds used for casting concrete cubes, which are crushed to determine the compressive strength of concrete. Eight apparatuses were fabricated using a $5 \mathrm{~mm}$ flat steel sheet plate cut into various shapes. These sheet plates are securely held to the base and vertical sides with the use of hinges while the two extended ends were fastened with removable two $17 \mathrm{~mm}$ bolt and nuts, each, through the holes bored on them. A sheet plate is slotted into the grooves, made in the mid-points of the inner surfaces of the longer vertical sheet plates and base sheet plate, resulting in a double-cell concrete cube mould. The concrete cube moulds are fabricated at an estimated total cost of $\$ 1,696: 50$ amounting to $\$ 11,462: 06$ per double-cell concrete cube mould.
\end{abstract}

Keywords: Concrete, compressive strength, mould apparatus, effectiveness and cheapness.

\section{INTRODUCTION}

Concrete is the most versatile and widely used material of construction of diverse structures for several purposes nowadays. It is basically obtained from the mixture of cement, fine aggregates, coarse aggregates and water in a specified proportion. The strength of concrete is commonly considered the most valuable and vital property. Consequently, tests have to be carried out for quality control and compliance with specifications. The most common of all the tests on hardened concrete is the compressive strength; partly because it is an easy test to perform and partly because many of the desirable characteristics of concrete are qualitatively related to its strength. Compressive strength tests of concrete are to determine the strength of concrete at transfer of stress or at the time of the removal of formwork (Neville, 2000). These test specimens are cast in steel or cast-iron moulds of obtain expected results that are comparable with that obtained in the field. And such results obtained can be used to enhance good quality job. Moreover, Nigeria is in dire need of technological advancement today; hence the governments, private firms and individuals are concerned about the standard and quality of construction work through which the greater expectation of technological breakthrough in the country could be started in earnest. However due to negligence, insincerity, lackadaisical attitude, lack of self confidence and economic challenges involved in construction work, we have been myopic about the improvement and provision of our laboratory equipment through fabrication of the basic apparatus which robust construction, generally $150 \mathrm{~mm} \times 150 \mathrm{~mm} \times 150 \mathrm{~mm}$, which should conform within narrow tolerances to the cubical shape, prescribed dimensions and plainness, (Neville, 2000). They are made in such a manner as to facilitate the removal of the molded specimen without damage and are so machined that when it is assembled ready for use, the dimensions and internal faces are required to be accurate, (Shetty 2005). "The height of the mould and the distance between the opposite faces are of the specified size $\pm 0.2 \mathrm{~mm}$ while the angle between adjacent internal faces and between internal faces and top and bottom planes of the mould is required to be $90^{\circ} \pm 0.5^{\circ}$, (Shetty, 2005). The concrete cube mould consists of a square flat steel sheet base and four vertical square flat steel sheet sides with clamps or bolt and nuts used in facilitating the assembly of the mould. The mould is properly clamped or bolted together during casting in order to prevent leakage of mortar. Before and after the assembly the mould, its mating surfaces are covered with mould oil, and a thin layer of similar oil is applied to the inside surfaces of mould, in order to prevent the development of bond between the mould and the concrete cube.

\section{BACKGROUND}

BS 1881: Part 108:1993 describes the methods for making cubes from concrete, (Neville, 2000). The concrete cube moulds are used in casting or molding concrete cubes used in the determination of compressive strength of concrete by crushing with the use of compression testing machine. The design and fabrication of concrete cube mould apparatus is of vital importance to the civil engineering and building technology laboratories; both in tertiary institutions and construction industries for the purpose of executing practical to could enhance the development and growth of the technology of this country. According to Audu (2007), a philosopher inferred that creativity is the outcome of rearrangement of consensual system of pattern and connection, which bolsters the fact that novelty, is constructed from that which already exists. There is a popular saying that necessity is the mother of invention. Necessity is the catalyst that motivated this researcher into the reality of the provision of more concrete cube moulds in the geotechnics laboratory of the department of civil engineering technology, Federal Polytechnic, Mubi. The recent increase in research work in concrete, made the reality of insufficient concrete mould apparatuses dawn on 
the researcher; thereby compelling him to undertake the design and fabrication of the double-cell concrete cube mould apparatuses: to enhance academic learning, acquire practical and technical experience for envisioned technological breakthrough.

In the design and fabrication of the concrete cube moulds, the properties of the steel (used) such as strength, durability, hardness, toughness and thickness were considered to prevent distortion when in use.

Design refers to a plan or convention for the construction of an object or system (as in architectural blue prints, engineering, etc). It is a roadmap or a strategic approach for someone to achieve a unique expectation. It defines the specifications, plans, parameters, costs, activities, processes and how and what to do and often necessitates considering the aesthetic, functional, economic and sociopolitical dimensions of both the design process. It may involve considerable research, thought modeling, interactive adjustment and redesign, (www.en.wikipedia.org/wiki/design).

Fabrication as an industrial term refers to building metal structures by cutting, bending and assembling. The cutting part of the fabrication is via sawing, shearing or chiseling (all with manual and powered variety torching with handheld torches, such as oxy-fuel torches). The assembling (joining of the pieces) is through welding; binding with adhesives, riveting, threaded fastness, e.t.c. Structural steel and sheet are the usual starting material for fabrication along with the welding wire, flux and fasteners that will join the cut pieces. As with other manufacturing processes, human labours are commonly used. The raw material has to be cut to size. This is done by variety of tools. The most common way of cutting is shearing. Welding is the main focus of steel fabrication. The formed and machined parts will be assembled and tack welded into place and then re-checked for accuracy. (www.en.wikipedia.org/wiki/fabrication(metal) ).

Design and fabrication is being carried out to provide for more apparatuses in the laboratory and thereby averting the importation of the usually very expensive ones. "If speed, economy and performance are the deciding factors in construction work, then the importance of design and fabrication of test apparatus should reign supreme in civil engineering field and individuals", (Audu, 2007).

\section{MATERIALS AND METHOD}

\subsection{MATERIALS}

1). $5 \mathrm{~mm}$ thick sheet steel plate

2). $17 \mathrm{~mm}$ bolt and nut.

3). $105 \mathrm{~mm}$ hinges.

4). $80 \mathrm{~mm}$ hinges

Other materials and equipment employed in the process of fabrication are

1) Angle grinder machine.

2). Arc welding machine.

3). Cutting disk.

4). Filing disk.

5). $2.5 \mathrm{~mm}$ electrodes

6). Measuring tape.

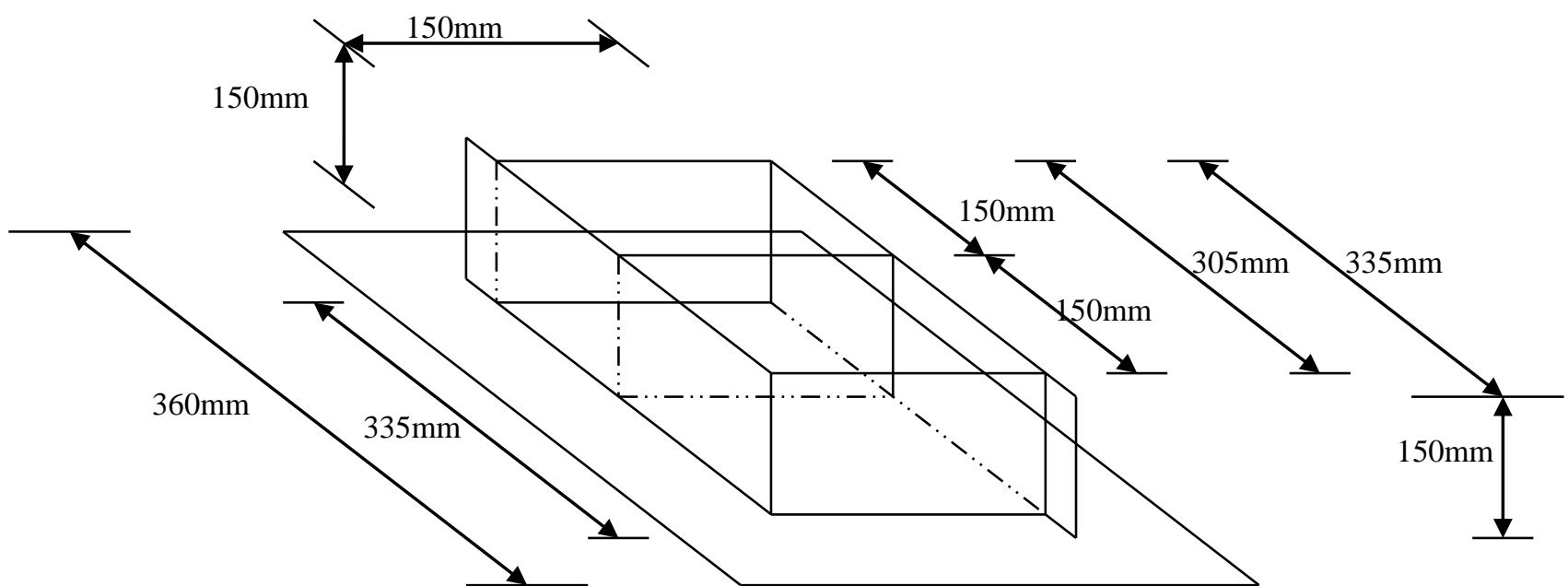

Fig. 3.1 Dimensions of the Fabricated Double-cell Concrete Cube mould.

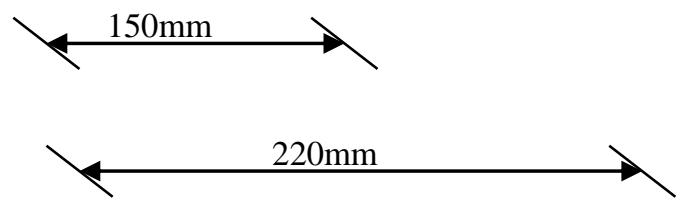




\subsection{METHOD/CONSTRUCTION TECHNIQUES}

The dimensions of the base and longer and shorter vertical steel sheet plate sides, as given in Fig. 3.1 above, were measured and marked out on the sheet metal. These square and rectangular shapes were then cut out with the use of cutting disk which was attached to the angle grinder machine. The cut-edges of the cut-out sheet plates were then filed to obtain smooth edges using the filing disk which was connected to the angle grinder machine. The two longer vertical sheet plates $(335 \mathrm{~mm}$ long) were connected to the base sheet plate, at $150 \mathrm{~mm}$

distance apart, by welding a pair of $110 \mathrm{~mm}$ hinges to the base plate and the longer vertical steel sheet plate sides. One edge of the longer steel sheet plates was joined to one edge of the shorter vertical steel sheet plate, measuring $150 \mathrm{~mm}$ by $150 \mathrm{~mm}$, at right angle, at the opposite ends, with the use of hinges by welding. Thereafter, pieces of $5 \mathrm{~mm}$ thick and $20 \mathrm{~mm}$ wide steel sheet plates were welded to the other edges of the shorter vertical opposite steel sheet plate sides, at right angle, thereby making such edges to extend outward to meet and flushed with the extended ends of the longer vertical sheet plates, on either side-ends of the mould. Two holes each, where bored on the extended side-ends of the longer and shorter vertical steel sheet plates (as passage provisions for the bolt and nut) using the arc welding machine and electrodes. A $16 \mathrm{~mm} \times 17 \mathrm{~mm}$-ends flat spanner was used to tighten four bolt and nuts (passing through the bored holes) to connect the side-ends of the vertical steel plates to form a rectangular mould. Grooves of $5 \mathrm{~mm}$ deep were made into the midpoints of the base steel sheet plate and the inner surfaces of the vertical longer steel sheet plates. Thereafter a piece of $155 \mathrm{~mm} \times 155 \mathrm{~mm}$ steel sheet plate was slotted into the grooves, made in the mid-points of the inner surfaces of the long vertical sheet plates and base sheet plate, parallel to the short vertical sheet plates, resulting in a double-cell concrete cube mould. The dimensions of the double-cell concrete cube mould apparatus are shown in Fig. 3.1, while appendix 1 depicts the pictorial representation.

\section{RESULTS AND DISCUSSIONS} 4.1 RESULTS

Given in table 4.1 below is the result of the estimated cost of fabricating eigth double-cell concrete cube mould apparatuses

TABLE 4.1 COST ESTIMATION FOR THE FABRICATION OF THE DOUBLE-CELL CONCRETE CUBE MOULD APPARATUSES

\begin{tabular}{|c|c|c|c|c|c|}
\hline $\mathrm{S} / \mathrm{N}$ & ITEM & QUANTITY & UNIT & $\begin{array}{l}\text { RATE } \\
\text { P }\end{array}$ & $\begin{array}{l}\text { AMOUNT } \\
\text { K } \\
\end{array}$ \\
\hline 1 & $\begin{array}{l}5 \mathrm{~mm} \text { thick steel sheet } \\
\text { plate }\end{array}$ & 1 & $\mathrm{~m}^{2}$ & $40,000: 00$ & $40,000: 00$ \\
\hline 2 & $17 \mathrm{~mm}$ bolt and nut & 32 & No. & $40 \quad: 00$ & $1,280: 00$ \\
\hline 3 & $110 \mathrm{~mm}$ hinges & 16 & No. & $300: 00$ & $4,800: 00$ \\
\hline 4 & $80 \mathrm{~mm}$ hinges & 32 & No. & $125: 00$ & $4000: 00$ \\
\hline 5 & Cutting disk & 5 & No. & $500: 00$ & $2,500: 00$ \\
\hline 6 & Electrodes & $1 \frac{1}{1}$ & Pkt. & $1,500: 00$ & $2,250: 00$ \\
\hline 7 & Paint & 1 & Gallon & $2,500: 00$ & $2.500: 00$ \\
\hline 8 & Labour & & & & $30,000: 00$ \\
\hline 9 & Total & & & & $87,330: 00$ \\
\hline 10 & Contingency & $\begin{array}{l}5 \% \text { of total } \\
\text { expenditure }\end{array}$ & & & $4,366: 50$ \\
\hline 11 & Total cost & & & & $91,696: 50$ \\
\hline
\end{tabular}

\subsection{DISCUSSION}

The double- cell concrete cube mould was fabricated using a $5 \mathrm{~mm}$ thick flat steel plate which was cut into various sizes. Six pieces, which comprised one $360 \mathrm{~mm}$ by $220 \mathrm{~mm}$, two $335 \mathrm{~mm}$ by $150 \mathrm{~mm}$, two $150 \mathrm{~mm}$ by $150 \mathrm{~mm}$ and one $155 \mathrm{~mm}$ by $155 \mathrm{~mm}$ sheet plates, respectively, were used to fabricate one double-cell concrete cube mould each. Other items such as two pairs of $80 \mathrm{~mm}$ hinges and one pair of $110 \mathrm{~mm}$ hinges and two pairs of $17 \mathrm{~mm}$ bolt and nuts were used in the fabrication. The widest steel sheet plate serves as the base of the mould. The two longer steel sheet plates and two shorter steel sheet plates were positioned vertically on the base plate. The longer side plates were held with a pair of hinges, each, unto the base plate, at $150 \mathrm{~mm}$ apart; while one edge of the shorter side plate was held unto one edge of the longer side plate, with one hinge, each, at the opposite ends, at $305 \mathrm{~mm}$ apart, all with the use of weld. The fabrication provides for the use 
of a pair of $17 \mathrm{~mm}$ bolt and nuts at the extended edges on the opposite sides and opposite ends, for fastening and the slotting of a central steel sheet plate of $155 \mathrm{~mm}$ by $155 \mathrm{~mm}$, thereby resulting in two moulds, measuring $150 \mathrm{~mm}$ by $150 \mathrm{~mm}$ by $150 \mathrm{~mm}$ each, in one single structural mould. In all, eight double-cell concrete cube moulds were fabricated at an estimated cost of $\$ 91,696: 50$, amounting to $\$ 11,462: 06$ per one doublecell concrete cube mould. This is far cheaper than the imported type, whose market price is far above $\$ 20,000$ for one single concrete cube mould, excluding importation and other service charges. This double-cell concrete cube mould is also more practically efficient in terms of time and application.

\section{CONCLUSIONS}

Based on the result of the successful design and fabrication of the double-cell concrete cube mould, the following conclusions are drawn;

1) The number of apparatus and volume of work practicable have been increased and this will in no small measure facilitate and enhance the research needs.

2) The materials used for the fabrication are very good and efficient and meet the standard specifications.

3) The cost of construction and maintenance are low while the operational method is easy.

4) The dimensions of the double-cell concrete cube moulds fared very well having met the standard specification.

5) The weight of the fabricated apparatus is light, which will facilitate easy application when compared to that supplied to the laboratory.

6) The cost of the fabricated apparatus is very cheap at 11,462:06 per double-cell mould and easy to procure when compared to that supplied to the laboratory which costs far above 20,000 per single-cell mould and very easy to procure.

\section{REFERENCE}

[1] Audu V.E.M (2007). Design and Construction of a Compacting factor Apparatus for the measurement of Workability of Concrete. Unpublished paper presented at the $7^{\text {th }}$ Annual National Engineering Conference, Federal Polytechnic, Mubi.

[2] BS 1881: Part 103: 1993. Method for making of test cubes from fresh concrete. Her Majesty Stationary Office, 2 Park Street London, WIABS.

[3] Neville, A. M. (2000). Properties of Concrete (fourth edition) Pearson Education Asia, Pte Ltd, Edinburgh gate Harlow Essex CM 202JE, England.

[4] Shetty, M.S. (2005). Concrete Technology, theory and Practice (sixth edition). S. Chard and Company Ltd, (An Iso 9001: 2000 Company) Ram Nagar, New Delhi 110055.

[5] www. en. wikipedia.org/wiki/design

[6] www.en.wikipedia.org/wiki/fabrication/(metal)
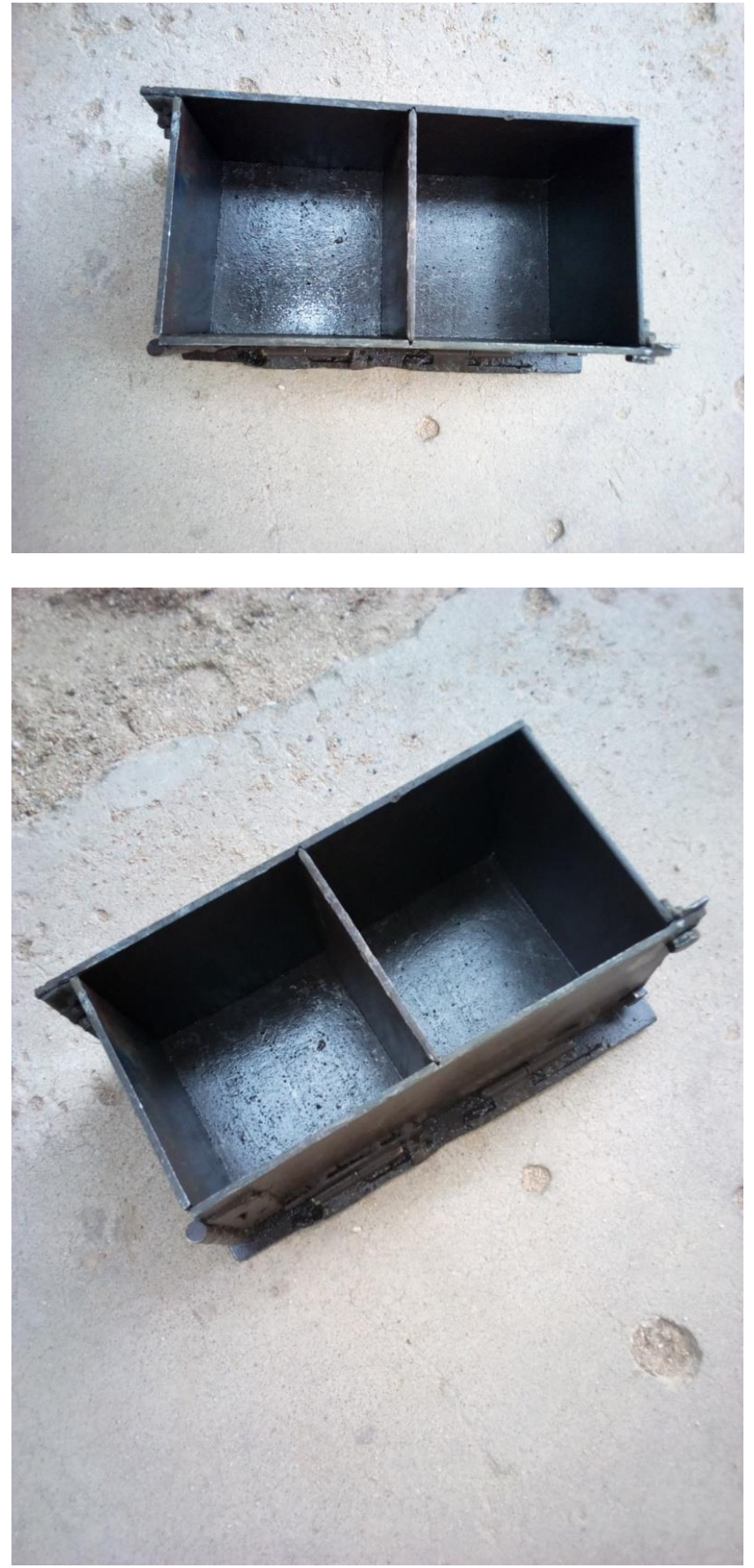

Appendix 1. THE FABRICATED DOUBLE-CELL CONCRETE CUBE MOULD APPARATUSES 